\title{
Bankziska as Lazismu Innovation and BMT Hasanah in Economic Empowerment in Ponorogo
}

\author{
Moh. Faizin1,Faruq Ahmad Futaqi ${ }^{2}$, Maulida Nurhidayati ${ }^{3}$ \\ 1,2,3IAIN Ponorogo \\ faizin@iainponorogo.ac.id ${ }^{1}$, futaqifaruq@gmail.com², \\ nurhidayati@iainponorogo.ac.id ${ }^{3}$
}

Received: 10 April 2021; Revised: 21 June 2021; Published: 30 June 2021

\begin{abstract}
ABSTRAK
Tujuan dari penelitian ini adalah untuk menganalisis inovasi yang dilakukan Lazismu Jawa Timur dengan BMT Hasanah Ponorogo yang diberi nama Bankziska. Metode analisis yang digunakan dalam penelitian ini adalah teknik deskriptif-kualitatif dan interpretatif. Temuan penelitian ini adalah Bankziska merupakan kepanjangan Bantuan Keuangan Berbasis Zakat Infak Shodaqoh dan Dana Sosial Keagamaan Lainnya. Sumber permodalan Bankziska didapatkan dari Lazismu dan BMT Hasanah dimana manajemen pengelolaan Bankziska dilaksanakan oleh BMT Hasanah. Bankziska memberikan pinjaman lunak tanpa bunga, tanpa jaminan, tanpa denda, tanpa biaya, dan tanpa sita kepada para pengusaha super mikro, mikro dan kecil yang terkena pinjaman rentenir (bunga). Manfaat lain dari Bankziska adalah adanya pendampingan keagamaan bagi para pengusaha yang melakukan pinjaman.
\end{abstract}

Kata kunci: BanZiska; Inovasi; Modal; Pemberdayaan; Rentenir

\section{ABSTRACT}

The purpose of this study is to analyze the innovations made by Lazismu East Java with BMT Hasanah Ponorogo named BankZiska. The analysis method used in this study is descriptive-qualitative and interpretive techniques. The findings of this study are Bankziska stands for Zakat-based Financial Assistance Infak Shodaqoh and Other Religious Social Funds. Bankziska's capital source is obtained from Lazismu and BMT Hasanah where bankziska management is implemented by BMT Hasanah. BankZiska provides interest-free, unsecured, no-fines, no-fee, and no-f confiscated loans to micro, micro and small super-entrepreneurs affected by loan sharks (interest). Another benefit of BankZiska is the existence of religious assistance for entrepreneurs who make loans.

Keywords: Banziska; Innovation; Capital; Empowerment; loan shark 


\section{PENDAHULUAN}

Dampak dari pandemi COVID-19 tidak hanya dirasakan oleh Indonesia saja, tetapi juga dirasakan oleh seluruh negara di dunia. Selain dari sektor kesehatan, dampak yang paling dirasakan juga terjadi pada sektor perekonomian. Dampak tersebut berupa meningkatnya angka pengangguran serta terhentinya aktivitas ekonomi masyarakat secara umum (Hadi Suwoso et al., 2020). Upaya yang dilakukan pemerintah dalam penanggulangan wabah COVID-19 salah satunya dengan membuat kebijakan pembatasan sosial baik sekala kecil maupun besar. Dampak dari kebijakan ini tentu saja berimbas pada terhentinya aktivitas masyarakat, hal ini memberikan pengaruh pada hilangnya sebagian besar pekerjaan di sektor formal, serta pada ujungnya memberikan efek domino pada hilangnya pendapatan masyarakat pada sektor informal yang umumnya mengandalkan pada penghasilan yang bersifat harian ataupun pekerjaan yang berkaitan dengan mobilisasi penduduk (transportasi) (Rahma et al., 2020), (Hadiwardoyo et al., 2020).

Pandemi COVID-19 sangat berdampak pada sektor perekonomian, khususnya sektor ekonomi riil. Data BPS tahun 2018 menunjukkan bahwa jumlah pelaku UMKM berada pada angka 64,2 juta unit usaha. Pada saat yang sama sektor UMKM mampu memberikan kontribusi PDB Indonesia sebesar 60,3\%. Artinya lebih dari setengah PDB negara ini disumbang oleh para pelaku usaha kecil. Tidak hanya itu, berdasarkan data juga diketahui bahwa 97\% total tenaga kerja yang ada diserap oleh UMKM dan 99\% dari total lapangan pekerjaan yang ada (Edward UP Nainggolan, 2020). Hingga akhir 2020 ini diyakini pastinya angka tersebut akan sangat mengalami kenaikan tajam akibat pengalihan para pekerja sektor formal berpindah ke sektor informal. Kenyataan yang lain menunjukkan bahwa dari sekian banyak UMKM yang ada di Indonesia ternyata baru sekitar $12 \%$ saja yang sudah terlayani (mengkases) perbankan (Rachmawati, 2020). Dari sini dapat diketahui ternyata masih sangat banyak para pelaku UMKM yang membutuhkan akses modal dalam kegiatan usahanya.

Hilangnya kesempatan pekerjaan akibat terjadinya PHK pada sektor pekerja formal, menjadikan sebagian besar dari mantan pekerja tersebut kembali pulang ke kampung halaman dan membuka usaha kecil-kecilan di lingkungan rumah. Pada saat yang sama anggota masyarakat yang sebelumnya telah bekerja di sektor informal juga mengalami kesulitan(Hartomo, 2020; Tempo, 2020). Hal ini selain disebabkan karena menurunnya daya beli yang berdampak pada sepinya permintaan, juga disebabkan permasalahan modal yang digunakan 
untuk usaha habis atau berkurang karena sebelumnya digunakan untuk bertahan hidup saat awal pandemi.

Permasalahan modal pada usaha kecil, menjadi peluang pintu masuk bagi para rentenir untuk memberikan pinjaman modal usaha. Kemudahan dalam mendapatkan pinjaman tanpa ada persyaratan yang berbelit-belit sering kali menjadi alasan bagi para pelaku usaha mikro kecil untuk melakukan pinjaman. Walaupun terkesan mudah dan menguntungkan, jerat rentenir ini mutlak dirasakan oleh pelaku usaha kecil akibat beban bunga yang besar dan memberatkan. Hal ini umumnya terjadi pada para pedagang kecil di pasar serta masyarakat kecil di kampung-kampung(Parlina, 2017).

Jerat rentenir yang bermula dari permasalahan modal para pelaku usaha kecil memerlukan sebuah solusi kongkrit dalam menyelesaikan permasalahan tersebut. Peningkatan dan upaya pemberdayaan ekonomi masyarakat tidak hanya merupakan tanggung jawab pemerintah secara umum, tetapi juga bagian penting bagi tanggung jawab sosial khususnya Lembaga Amil Zakat Infak dan Sedekah (LAZIS) dan Baitul Mal wa Tanmil. Peran kedua lembaga ini menjadi sangat penting dalam meningkatkan kualitas pemberdayaan ekonomi umat melalui pelaksanaan program pendistribusian zakat produktif (Ridwan, 2019). Senada dengan hal tersebut, hasil penelitian yang dilakukan (Ridwan et al., 2020) menyebutkan bahwa pelaksanaan zakat produktif berupa pemberdayaan ekonomi dinilai sangat membantu dalam upaya pengentasan umat dari jurang kemiskinan. Selain memperoleh dana umumnya mereka juga mendapatkan bimbingan keterampilan berwirausaha. Penelitian (Ramadhanu \& Widiastuti, 2017) juga menyebutkan bahwa pemberdayaan ekonomi umat selain berdampak pada sektor ekonomi juga berdampak pada peningkatan akidah.

Penelitian yang dilakukan oleh Rizki Afri Mulia (2019) menunjukkan bahwa program KJKS yang dilakukan BMT dalam memberdayakan ekonomi UMKM telah efektif dengan memberikan pembiayaan dalam penambahan modal dalam mengembangkan usaha mereka. Walaupun demikian program ini belum sepenuhnya meningkatkan kesejahteraan kesemua anggotanya, hal ini ditunjukkan dengan masih adanya kendala internal (kurangnya modal KJKS, pola pikir masyarakat miskin, kurangnya pengawasan) dan kendala eksternal berupa pemanfaatan dana bantuan yang dianggap belum maksimal, kondisi masyarakat yang tidak stabil, serta persaingan dengan rentenir (Mulia, 2019). Penelitian Sukma Indra (2018) menunjukkan bahwa Baznas Provinsi Kalimantan Barat menerapkan dua pemberdayaan ekonomi yaitu ekonomi konsumtif dan produktif bagi masyarakat miskin. Pelaksanaan program ini masih memiliki 
kekurangan yaitu kurang dana zakat, kurangnya dana operasional, kurangnya SDM, serta kurangnya dukungan instansi terkait(Indra, 2018).

Kabupaten Ponorogo dengan jumlah penduduk sebanyak 871,370 orang dan jumlah penduduk miskin berdasarkan data tahun 2019 sebesar 9,64\% (BPS, 2020). Kenyataan ini, tentunya diyakini semakin diperparah akibat terjadinya pandemi COVID-19 yang terjadi di awal tahun 2020 hingga saat ini. Tingginya angka kemiskinan di kabupaten Ponorogo merupakan tantangan tersendiri bagi Lembaga Amil Zakat Infak dan Sedekah (LAZIS) dan Baitul Maal wa Tamwil yang ada di kabupaten Ponorogo, mengingat jumlah dan daya jangkau kedua lembaga tersebut yang teramat terbatas. Disisi lain tidak semua LAZIS mampu mengelola zakat produktif secara tepat dan berkelanjutan. Hal ini disebabkan karena keterbatasan anggaran serta kurangnya SDM dalam pengelolaan dana tersebut(Thoharul Anwar, 2018). Begitu pula hal yang sama terjadi pada BMT, secara umum masyarakat masih menganggap bahwa BMT tak ubahnya lembaga peminjaman modal yang lain, yang menerapkan persyaratan yang rumit dan bunga yang memberatkan(Ajija et al., 2018). Hal ini menjadikan alasan mengapa sebagian besar dari pelaku usaha kecil enggan ke BMT sehingga tidak bisa lepas dari jerat rentenir.

Salah satu BMT di kabupaten Ponorogo adalah BMT Hasanah. Dengan tujuan untuk meningkatkan perekonomian masyarakat, sekaligus berupaya untuk memutus mata rantai jerat rentenir. BMT Hasanah bekerjasama dengan LazisMU Jawa Timur membuat terobosan berupa Co-Branding BANKZISKA. Kerjasama tersebut diwujudkan dengan menerapkan pembiayaan kepada masyarakat kecil tanpa ribet, tanpa jaminan, tanpa biaya administrasi, tanpa margin/bunga dan tanpa tambahan serta dengan angsuran sangat lunak dan sangat terjangkau. Sistem pembiayaan ini nantinya selain menerapkan pemberdayaan ekonomi sekaligus upaya dakwah dalam melepaskan para pelaku usaha kecil dari jerat rentenir. Gap pada penelitian ini adalah adanya inovasi pelaksanaan program zakat produktif di Lembaga Amil Zakat yang bekerjasama dengan BMT yang menjadi subyek penelitian sebelumnya dan menjadi fokus penelitian saat ini. Berangkat dari latar belakang tersebut, penelitian ini mengambil judul BanZiska sebagai Inovasi Lazismu dan BMT Hasanah dalam Pemberdayaan Ekonomi di Ponorogo. 


\section{METODE PENELITIAN}

Pendekatan penelitian dalam penelitian ini adalah pendekatan deskriptif kualitatif. Subyek penelitian adalah LAZISMU wilayah Jawatimur dan BMT Hasanah Ponorogo. Obyek penelitian yang dikaji oleh peneliti dalam penelitian ini adalah produk BANKZISKA yang merupakan produk Co-Branding antara LazisMU wilayah Jatim dan BMT Hasanah. Sumber data dalam penelitian ini berasal dari peristiwa atau aktivitas yang diobservasi oleh peneliti adalah peristiwa dan aktivitas yang terjadi di BANKZISKA dari informasi orang-orang yang berperan dan terlibat dalam produk co branding BANKZISKA serta dokumen dan berkas-berkas terkait dengan BANKZISKA.

\section{HASIL PENELITIAN DAN PEMBAHASAN}

\section{Kerjasama Lazismu dan BMT Hasanah}

Bankziska merupakan kepanjangan dari Bantuan Keuangan berbasis Zakat, Infak, Shodaqoh, dan Dana Sosial Keagamaan Lainnya. Bankziska bukanlah merupakan Bank sebagaimana dalam Undang-Undang perbankan yang berlaku di Indonesia (Sumanto et al., 2021). BANKZISKA adalah produk co-branding antara Lembaga Amil Zakat Lazismu Wilayah Jawa Timur dengan Lembaga Keuangan Syariah BMT Hasanah Ponorogo. Co-branding menurut Goni merupakan bentuk kerjasama dua merk (brands) dalam bentuk kolaborasi produk atau kolaborasi pemasaran (Goni, 2007). Tujuan dilakukannya cobranding untuk menarik minat konsumen dan menjangkau konsumen secara lebih luas sehingga pasar dan keuntungan akan semakin meningkat (Rangkuti, 2008). Co-branding yang dijalankan oleh Lazismu wilayah Jatim dengan Lembaga Keuangan Syariah sebenarnya tidak untuk tujuan bisnis, namun untuk pemberdayaan. Penggunaan istilah co-branding mencerminkan kolaborasi Lazismu dan Lembaga Keuangan Syariah yang memiliki tujuan sosial yaitu pemberdayaan dan pengentasan usaha super mikro, mikro dan kecil dari jeratan rentenir (Sumanto et al., 2021). Senada dengan itu Hudaifah menyatakan bahwa optimalisasi dan ketepatan pengelolaan zakat saat ini merupakan salah satu solusi untuk mengatasi kemiskinan dan pemberdayaan ekonomi kecil (Hudaifah et al., 2020). 
Ketua Lazismu Jatim Zainul Muslimin menyatakan:

“Program ini sebenarnya masih baru dan merupakan unggulan dari Lazismu Jatim, program satu-satunya yang dijalankan oleh Lazismu untuk pengentasan usaha super mikro dan kecil dari jeratan rentenir. Program ini dibuat secara sistematis dan profesional ada kantor dan juga laporanlaporannya".

Berdasarkan hasil wawancara yang dilakukan tersebut diketahui bahwa alasan adanya bekerjasama dengan lembaga keuangan syariah untuk memudahkan sistem berjalan dengan baik, cepat membesar dan dapat diduplikasi ke seluruh wilayah Indonesia.

Hal senada juga disampaikan oleh Sulistio, Ketua BMT Hasanah yang digandeng untuk menjalankan program ini menyatakan bahwa program BankZiska telah sejalan dengan tujuan dari lembaga yang dipimpinnya, yaitu untuk pemberdayaan ekonomi umkm. Adanya program Bankziska menurut Sulistio akan sangat membantu usaha mikro kecil karena selama ini pembiayaan atau kredit di masyarakat menggunakan tambahan atau biayabiaya. Namun, dengan BankZiska pengusaha mikro kecil dipinjami tanpa tambahan sama sekali dan lunak pembayarannya. Sebagaimana disampaikan (Ajija et al., 2018) bahwa BMT merupakan organisasi ekonomi yang difokuskan untuk pengembangan usaha mikro dan pengentasan kemiskinan. Keberadaan produk BankZiska bersambung kait dengan fungsi utama dari BMT (Lembaga Keuangan Mikro Syariah). Jika BMT menggunakan pembiayaan syariah yang masih menggunakan marjin, bagi hasil atau ujrah, produk BankZiska sama sekali tanpa tambahan.

Lebih lanjut, Agus Edi S selaku Direktur Utama BankZiska yang ditunjuk oleh Lazismu Wilayah Jatim menegaskan bahwa masyarakat usaha mikro kecil saat ini banyak yang terjerat rentenir atau peminjaman dengan bunga tinggi. Banyak para tengkulak uang yang menjajakan pinjaman dengan bunga diatas rata-rata bahkan sangat mencekik di masyarakat utamanya pasarpasar tradisional. Akibatnya para pengusaha mikro kecil tidak mampu berkembang dengan baik bahkan bangkrut. Maka, BankZiska hadir dengan memberikan pinjaman tanpa tambahan, tanpa biaya, tanpa jaminan, tanpa denda dan tanpa sita kepada masyarakat. Model penyaluran ZIS biasanya dengan memberikan bantuan pemberian modal. Melalui program BankZiska penyaluran tidak dengan pemberian, namun pinjaman, yaitu model pinjaman akad qordhul hasan (pinjaman kebajikan). Lambat laun dengan besarnya 
program BankZiska ini maka pinjaman model rentenir dapat diberantas di masyarakat.

Konsep co-branding yang dijalankan oleh Lazismu dan BMT Hasanah dalam bentuk BankZiska memiliki konsep unik karena BankZiska merupakan produk kolaborasi yang dibuat untuk penyaluran dana ZIS dengan model pinjaman tanpa tambahan. Fokus dari pinjaman inipun untuk pembebasan usaha mikro kecil dari jeratan rentenir yang banyak dijumpai di masyarakat. Keberadaan pinjaman bunga tinggi yang kuat di masyarakat diimbangi dengan hadirnya pinjaman tanpa bungan BankZiska. Disatu sisi, BMT Hasanah juga mendapat citra baik dari para umkm dengan adanya program pinjaman BankZiska.

\section{Pelaksanaan Co-Branding BankZiska dan BMT Hasanah}

Dalam melaksanakan co-branding antara Lazismu dan BankZiska telah dituangkan dalam kesepakatan. Hal ini tercermin dalam buku pedoman BankZiska tentang apa saja yang harus dilakukan oleh kedua belah pihak. Lazismu Wilayah Jatim memberikan bantuan modal pendirian BankZiska dan branding BankZiska, memberikan subsidi margin 1\% setiap bulan dari rata-rata outstanding pembiayaan qardul hasan dan memberikan kompensasi $100 \%$ atas pinjaman qardul hasan bermasalah. Sedangkan BMT Hasanah berkewajiban: Menyediakan ruangan minimal 3x4 meter, menyediakan modal pinjaman qardul hasan minimal Rp. 50.000.000,00 (lima puluh juta rupiah) dan menyiapkan manajemen dan menanggung seluruh operasional dari BankZiska. Selain permodalan dari BMT, Lazismu juga dapat memberikan modal kepada BankZiska setiap saat (Sumanto et al., 2021).

Dalam kolaborasi ini BMT Hasanah juga diberikan fasilitas pendirian Kantor Layanan Lazismu oleh Lazismu Wilayah Jatim. Hal ini dapat digunakan untuk penghimpunan dana ZIS sebagai penunjang operasional dari BankZiska (Sumanto et al., 2021). Menurut Sulistio seluruh operasional dan pengurusan administrasi mulai dari penyediaan SDM, proses permohonan pinjaman, akad dan pencairan serta angsuran pelunasan seluruhnya merupakan tanggung jawab dari BMT Hasanah. Namun, dalam pelaksanaan teknis dapat juga melibatkan relawan dari Lazismu setempat untuk koordinasi.

Walaupun menempel pada BMT Hasanah, menurut Agus Edi BankZiska memiliki ruang, sistem IT, pencatatan dan SOP tersendiri. Setiap bulan BankZiska BMT Hasanah melaksanakan laporan ke BankZiska pusat yang ada 
di Lazismu Wilayah Jawa Timur dan di tembuskan ke Lazismu Daerah setempat. Dalam akad BankZiska menggunakan akad qordhul hasan (pinjaman kebajikan). Syarat dan ketentuan penerima pinjaman juga cukup mudah, yaitu terkena pinjaman bunga, fotokopi ktp, fotokopi kk, dan foto usaha.

Dalam akad ini Mitra Bankziska (istilah bagi peminjam bankziska) hanya berkewajiban mengembalikan pokok pinjaman saja. Manakala terjadi kebangkrutan, sakit permanen atau meninggal dunia, maka BankZiska membebaskan sisa pinjaman yang ada. Besaran pinjaman yang diberikan oleh BankZiska maksimal 2.000.000 dan dalam kondisi tertentu dapat lebih dari 2.000.000 (Sumanto et al., 2021).

Tumiran, salah satu Mitra BankZiska yang berprofesi menjadi pedagang bakso dorong di Pasar Siman menyampaikan bahwa dia telah menikmati pinjaman dari BankZiska selama tiga kali. Pertama diberi pinjaman 300.000 lunas, kedua diberi pinjaman 300.000 lunas dan saat ini diberi pinjaman 500.000. Sebelumnya Tumiran memiliki pinjaman di bank thithil (pinjaman bunga tinggi). Seringkali baksonya tutup karena kekurangan modal. Sejak dipinjami oleh BankZiska saat ini dia terus mampu berjualan. Sekaligus sedikitdemi sedikit berusaha menghilangkan pinjaman bank thithilnya. Cicilan yang dibayarkan oleh Tumiran kepada BankZiska senilai 5.000-10.000 per hari pada saat dia berdagang bakso. Tumiran setiap hari didatangi oleh petugas BankZiska yang mengambil angsuran (Tumiran, 2021).

Ada lagi Tunar, pengrajin rinjing di daerah mlarak ponorogo juga telah menikmati pinjaman BankZiska. Dia memiliki pinjaman 500.000 rupiah dan dicicil setiap bulan 100.000 rupiah selama lima bulan. Tunar melakukan angsuran dengan cara didatangi oleh petugas bankziska setiap bulan. Selain di BankZiska saat ini Tunar juga memiliki pinjaman di Bank Thitil dengan model berbunga tinggi. Bersama teman-temanya saat ini Tunar menikmati pinjaman BankZiska dengan model kelompok tanggung renteng (Tunar, 2021).

Pemaparan di atas menunjukkan bahwa pelaksanaan operasional BankZiska sepenuhnya dilakukan oleh BMT Hasanah dengan permodalan dari kedua belah pihak (Lazismu dan BMT). BMT Hasanah tidak menanggung kerugian karena setiap kerugian yang terjadi atau gagal bayar semua dikompensasi oleh Lazismu. Termasuk BMT Hasanah mendapatkan subsidi marjin atas pembiayaan yang dilakukan senilai 1 persen dari outstanding (saldo pinjaman yang beredar) bulanan. Akad yang digunakan dalam pinjaman BankZiska adalah akad qordhul hasan dimana pinjaman pokok kembali pokok dengan model cicilan. Cicilan dapat dilakukan harian maupun bulanan. Kondisi ini sangat menguntungkan para peminjam (Mitra BankZiska) karena 
sama sekali tidak ada tambahan dalam pengembalian pinjaman, angsuran lunak dan hutang tersebut tidak dikembalikan manakala sakit tetap, meninggal atau usaha bangkrut.

\section{Manfaat BankZiska}

Dalam Buku Pedoman BankZiska dinyatakan bahwa program ini merupakan bentuk keprihatinan atas merajalelanya pinjaman bunga tinggi di masyarakat utamanya usaha super mikro, mikro dan kecil.

“Berawal dari keprihatinan terhadap merajalelanya pinjaman berbasis bunga (riba) utamanya yang dilakukan oleh para rentenir di masyarakat, maka Lazis Muhammadiyah Wilayah Jawa Timur merancang program pembebasan masyarakat UMK dari jeratan riba/rentenir. Program ini direalisasikan dalam bentuk bantuan pinjaman tanpa bunga, tanpa biaya administrasi, tanpa potongan dan tanpa jaminan kepada para pengusaha super mikro, mikro dan kecil" (Sumanto et al., 2021). Usaha super mikro, mikro dan kecil dalam ketentuan ini adalah usaha yang memiliki omset puluhan ribu sampai dengan dibawah 5 juta per hari.

Pernyataan ini menunjukkan bahwa fokus dari adanya BankZiska ini adalah untuk memberantas adanya pinjaman rentenir di masyarakat. Namun, selain itu Agus Edi S menyampaikan bahwa sebenarnya ada 3 proses tahapan yang akan dilakukan BankZiska untuk melakukan pemberdayaan pada usaha super mikro, mikro dan kecil. Pertama, membebaskan mereka dari rentenir, kedua memampukan mereka untuk berpindah permodalan kepada lembaga keuangan syariah, dan ketiga adalah mentransformasi mereka dari mustahik menjadi muzaki. Secara simultan ketiga proses tersebut diikuti dengan pendampingan ekonomi dan spiritual (Sumanto, 2021).

Hal ini juga disampaikan oleh Setyo Utomo, Relawan BankZiska kecamatan Mlarak Ponorogo yang menyampaikan bahwa setiap bulan ada pengajian yang dilakukan oleh BankZiska bersama mitra-mitra BankZiska di rumahnya. Para mitra bankziska berkumpul habis maghrib sampai isya' untuk mendengarkan tausiyah dan selanjutnya melakukan angsuran (Utomo, 2021). Kegiatan serupa juga dilakukan Budi Santoso, Relawan BankZiska Jetis Ponorogo. Setiap kali mengangsur bulanan selalu dilaksanakan di masjid Baitul Arqam Jintap dan didahului oleh tausiah keagamaan. Kegiatan ini menunjukkan bahwa Mitra BankZiska mendapatkan manfaat ekonomi pinjaman tanpa bunga yang lunak dan menikmati manfaat berupa pendampingan spiritual penguatan iman dan takwa (Santoso, 2021). 


\section{KESIMPULAN}

BankZiska merupakan produk kolaborasi yang memiliki kepanjangan Bantuan Keuangan Berbasis Zakat Infak Shodaqoh dan Dana Sosial Keagamaan Lainnya. BankZiska hadir dari keprihatinan Lazismu Wilayah Jawa Timur terhadap merajalelanya pinjaman berbunga tinggi (rentenir) yang berkembang di masyarakat. Lazismu Wilayah Jawa Timur membuat program co-branding bersama BMT Hasanah Ponorogo yang diberi nama BankZiska. Sumber permodalan BankZiska didapatkan dari Lazismu dan BMT Hasanah. Mekanisme BankZiska adalah memberikan pinjaman lunak tanpa bunga, tanpa jaminan, tanpa denda, tanpa biaya, dan tanpa sita kepada para pengusaha super mikro, mikro dan kecil yang terkena pinjaman rentenir (bunga). Adapun manajemen pengelolaan BankZiska dilaksanakan oleh BMT Hasanah. Saat pinjaman BankZiska telah dinikmati oleh para pedagang pasar tradisional dan pelaku usaha mikro kecil di daerah Ponorogo. Diantara manfaat dari BankZiska adalah pinjaman lunak tanpa bunga dan juga pendampingan keagamaan yang dilakukan oleh bankZiska.

\section{DAFTAR PUSTAKA}

Ajija, S. R. A., Hudaifah, A., Wasiaturrahma, Sulistyaningsih, L., A'yun, K. Q., Mukti, H. K., Salama, S. C. U., Rofiqoh, S. N. I., \& Azzizah, U. A. (2018). Koperasi Bmt: Teori, Aplikasi dan Inovasi. Inti Media Komunika. https:// books.google.co.id/books?id=CtWyDwAAQBAJ

BPS. (2020). Kabupaten Ponorogo dalam Angka 2020. Badan Pusat Statistik, 44.

BPS Provinsi Jawa Timur. (2020). Provinsi Jawa Timur dalam Angka 2020.

Edward UP Nainggolan. (2020). UMKM Bangkit, Ekonomi Indonesia Terungkit. Artikel DJKN.

Goni, R. (2007). Playing to Win - Langkah-langkah Cerdas. Gramedia Pustaka Utama. https:/ / books.google.co.id/books?id=T-5-SC3LDMgC

Hadi Suwoso, R., Febrianto, T., Kushindarto, D., Aziz, F., \& Tinggi Ilmu Kesehatan Kendal, S. (2020). Dampak Pandemi Covid-19 Bagi Perekonomian Masyarakat Desa. In jurnal.globalhealthsciencegroup .... 
Moh. Faizin : Banziska; Innovation; Capital; Empowerment; loan shark

Hadiwardoyo, W., Tinggi Ilmu Ekonomi Hidayatullah, S., \& Barat, J. (2020). Kerugian Ekonomi Nasional Akibat Pandemi Covid-19. ekonomis.unbari.ac.id. https://doi.org/10.24853/baskara.2.2.83-92

Hafidhuddin, D. (2002). Zakat dalam Perekonomian Modern. Gema Insani. https:/ / books.google.co.id/books?id=a6o2sAU07XkC

Handani. (2020). Mengenal Usaha Mikro Kecil dan Menengah (UMKM) Lebih Dekat. Uwais Inspirasi Indonesia.

Hartomo, G. (2020). Kena PHK Imbas Covid-19, Banyak Orang Kota Pulang Kampung Jadi Petani. https://ekbis.sindonews.com/read/243594/34/kena-phkimbas-covid-19-banyak-orang-kota-pulang-kampung-jadi-petani1606198312

Hudaifah, A., Tutuko, B., Abdurrubi P, S., Ishaq, A. A., \& Albar, M. (2020). Sinergi Pengelolaan Zakat di Indonesia. Scopindo Media Pustaka.

Indra, S. (2018). Economic Empowerment Model for the Poor Through Zakat Institution Under Maqashid Syariah Concept in West Kalimantan. Asian Journal of Social Science Studies, 3(1), 54. https://doi.org/10.20849/ajsss.v3i1.337

Mulia, R. A. (2019). Peranan Program Koperasi Jasa Keuangan Syariah Baitul Maal Wat Tamwil ( Kjks Bmt) Dalam Pemberdayaan Pelaku Usaha Mikro Kecil Menengah Di Kota Padang. Ensiklopedia Social Review, 1(3), 290-199.

Parlina, Y. (2017). Praktik Pinjaman Rentenir Dan Perkembangan Usaha Pedagang Di Pasar Prapatan Panjalin Majalengka. Inklusif (Jurnal Pengkajian Penelitian Ekonomi Dan Hukum Islam), 2(2), 100. https://doi.org/10.24235/inklusif.v2i2.1938

Rachmawati, A. R. (2020). Baru 12 persen umkm mengakses layanan perbankan. pikiran-rakyat.

Rahma, O. :, Mardiyah¹, A., \& Nurwati², R. N. (2020). Dampak Pandemi Covid19 Terhadap Peningkatan Angka Pengangguran Di Indonesia. In academia.edu.

Ramadhanu, A., \& Widiastuti, T. (2017). Model Pemberdayaan Ekonomi Mualaf 
Oleh Lembaga Amil Zakat: Studi Kasus LAZ BMH Pada Mualaf Suku Tengger 1). In e-journal.unair.ac.id.

Rangkuti, F. (2008). The Power of Brands. Gramedia Pustaka Utama. https:// books.google.co.id/books?id=-fppKehBDQEC

Ridwan, M. (2019). Pengelolaan Zakat Dalam Pemberdayaan Masyarakat Di Kota Cirebon. In jurnal.syntax-idea.co.id (Vol. 1, Nomor 4).

Ridwan, M., Andalasari, L., Setiani, R. I., \& Merliana, R. (2020). Jurnal Perbankan Syariah Jurnal EcoBankers Pengelolaan Zakat Produktif Melalui Program Senyum Mandiri Dalam Pemberdayaan Ekonomi Mustahiq Di Rumah Zakat Cabang Cirebon. In journal.bungabangsacirebon.ac.id (Vol. 1, Nomor 2).

Soemitra, A. (2015). Bank \& Lembaga Keuangan Syariah. Prenada Media. https://books.google.co.id/books?id=0SFADwAAQBAJ

Sugiono. (2017). Metode Penelitian Kuantitatif, Kualitatif, dan RED. Alfa Beta.

Sugiyono, P. (2011). Metodologi penelitian kuantitatif kualitatif dan R\&D. Alpabeta, Bandung.

Sumanto, A. E., Sahidu, M. A., \& Futaqi, F. A. (2021). Buku Pedoman BankZiska. Lazismu Jatim.

Tempo. (2020). Opini: Pandemi dan Fenomena Pulang Kampung oleh Khudori - Opini - koran.tempo.co. https://koran.tempo.co/read/opini/457696/opinipandemi-dan-fenomena-pulang-kampung-oleh-khudori?

Thoharul Anwar, A. (2018). Zakat Produktif Untuk Pemberdayaan Ekonomi Umat. ZISWAF: Jurnal Zakat dan Wakaf, 5(1), 41-62. 